\section{Rheological investigation of SBR/ CW/CB tricomposite used to create a sustainable procedure for idler rollers production}

\author{
Mohammed H. AL-MAAMORI - College of Materials Engineering, University of Babylon, Iraq \\ AbBass A. HASHIM = Professor, Director, Power of Technology Company, Sheffield, UK \\ - Engineering and Technology Department, University Campus, North Lincolnshire, UK \\ ALI I. AL-MOSAWI - University of Miskolc, Miskolc, 3515 Egyetemváros, Hungary \\ - qkoali76@uni-miskolc.hu
}

ShaYmaA AbBas ABDULSADA - University of Miskolc, Miskolc, 3515 Egyetemváros, Hungary

KÁLmÁN MAROSSY - University of Miskolc, Miskolc, 3515 Egyetemváros, Hungary

Érkezett: 2019. 09. 17. - Received: 17. 09. 2019. - https://doi.org/10.14382/epitoanyag-jsbcm.2019.25

\begin{abstract}
The concept of sustainability is now considered as the key of the future, not just for industry but also for all resources on this planet. The real guarantee for the continuation of life is by recycling all types of industrial waste using a method that combines a high level of efficiency and environmental pollution protection. This will create a sustainable resource that keeps earth's natural resources from depletion. In this study, we introduce a technological procedure for the use of cement waste in manufacturing engineering parts with high efficiency. Rheological analysis for styrene butadiene rubber has been investigated as function percentages additives (10-35 pphr) of cement waste (CW) and carbon black (CB). The rheological properties include torque and thermos-plasticity measured at temperature ranges of $165^{\circ} \mathrm{C}, 175{ }^{\circ} \mathrm{C}$ and $185{ }^{\circ} \mathrm{C}$. The tests showed that the cement waste has the ability and efficiency for improving the rheological properties of styrene butadiene rubber.

Keywords: SBR, cement waste, carbon black, rheological properties, sustainability

Kulcsszavak: SBR, cementhulladék, szénfekete, reológiai tulajdonságok, fenntarthatóság
\end{abstract}

Mohammed H. AL-MAAMOR Professor of Rubber Technology at Faculty of Materials Engineering. University of Babylon, IRAQ. Research Interests: Rubber Technology, Materials Testing, Materials Processing.

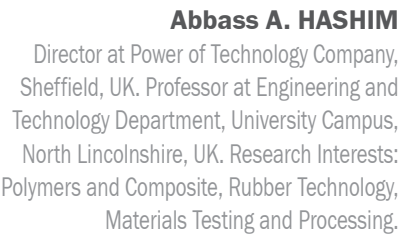

Ali I. AL-MOSAW

PhD Student at Institute of Ceramic and Polyme Engineering, Faculty of Materials Science and Engineering, University of Miskolc, Hungary. Research Interests: Polymers, Composite Materials, Rubber Technology, Flame Retardants, Materials Testing, Materials Processing

Shaymaa Abbas ABDULSADA PhD Student at Institute of Metallurgy, Faculty of Materials Science and Engineering, University of Miskolc, Hungary. Research Interests: Materials Testing and Processing, Engineering of Metallurgy, Corrosion Engineering, Heat Treatment of Metals, Casting of Metals.

Kálmán MAROSSY Professor of Polymer Engineering at Institute of Ceramic and Polymer Engineering, University of Miskolc, Hungary. Research Interests: Polymer Blends, Multiphase polymer systems, Relaxation phenomenon, Thermally stimulated discharge, Polymer degradation, Composite materials,

\section{Introduction}

Rubber has been used for a long time in many important industrial applications, because of its distinctive characteristics [1-3]. Researchers over the years conducted studies to develop its structure and characteristics not only by creating a new types of rubber, but also develop the existing types by adding fillers or changing processing conditions and study how its properties are affected. Rheological properties are greatly affected by the processing method and additives [4-8]. Because of rubber is a viscoelastic material, its rheological properties will change during processing. In addition, the presence of fillies within rubber composition such as carbon black or silicon dioxide will change the rheological behaviour of rubber making it more complex. The degree of change in processing conditions depends on the amount of the fillers [9-11]. When studying the rheological behaviour of rubber it is important to calculate the rate of flow at different conditions in terms of stress, applied time of stress, temperature and resilience [12-17].

Iraq's environmental regions near cement factories suffers from high concentrations of pollution [18-19]. This is due to the use of old cement factorization techniques and non-compliance with environmental standards and safety requirements. The use of filters to remove suspended dust in the air - which is a result of crushing raw materials - reduces gases emission throughout the process and dust coming out of the oven during the burning stage of raw materials and clinker crushing, are safe methods for disposal from this waste. All these environmental issues caused a significant damage for the surrounding areas of cement factories and travel to far areas by dust particles volatilization [20-21]. Therefore, it is necessary to provide an appropriate technological procedure to safely dispose the wastes for all types of industrial waste not just for cement waste, to be incorporate into useful engineering applications, where it can be used as fillers for rubber and polymers composition [22-36]. The main aim of this research is the use of cement waste as filler for styrene butadiene rubber (SBR) and to study the effect of this additive on the rheological properties in order to prove that these wastes are useful for manufacturing of idler rollers used in chain conveyors and elevators at grain silos of Iraqi State Trade Company.

\section{Methodology}

\subsection{Materials}

Styrene butadiene rubber type KER 1502 containing 23.5\% Styrene supplied by Synthos S.A., Poland; Carbon black type N375 supplied by Sullivan Qiao Shanghai King Chemicals Co., Ltd., China; Zinc oxide with supplied by Saha Metal San. Tic. Ltd. Şti, Turkey; Stearic acid supplied by Hefei TNJ Chemical Industry Co.,Ltd, China; Antioxidant 6PPD supplied by Flexsys Rubber Chemicals Ltd, Belgium; Accelerator MBS supplied by Richest Group, China. Paraffin Wax supplied by Kerax Limited, England; Sulfur supplied by 


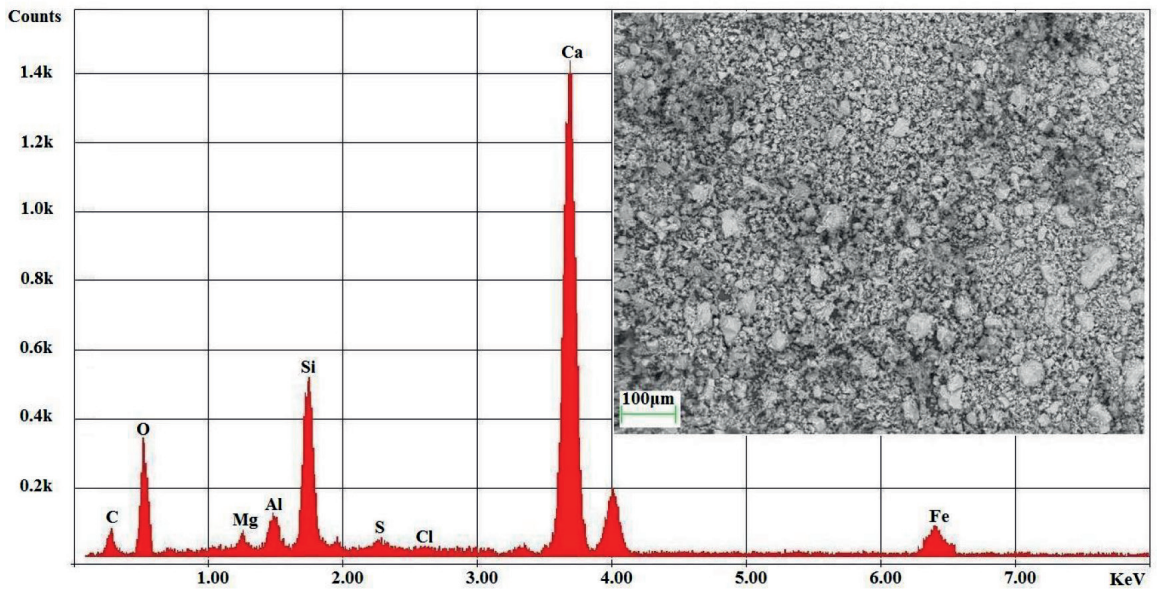

Fig. 1 SEM - energy dispersive X-ray microanalysis for cement waste

1. ábra A cement pásztázó elektronmikroszkóppal végzett energia-diszperzív röntgen mikroanalízise with $150 \mathrm{~mm}$ diameter and $300 \mathrm{~mm}$ length rotating with $24 \mathrm{rpm}$ speed. The cure characteristics for the four batches samples were evaluated according to the standard ASTM D2705 by using micro vision enterprises (MV-ODR) devise [37]. The test was done at temperature 165,175 and $185^{\circ} \mathrm{C}$ and $12 \mathrm{~min}$ for each sample.

\section{Results and discussion}

The rheological behaviour of SBR/CW/ $\mathrm{CB}$ tricomposite at different temperature ranges and percentages of $\mathrm{CW} / \mathrm{CB}$ additives are shown in Figs. 2, 3 and 4 respectively. From these figures we can
Leader Technologies Co.,Ltd, China; Processing oil supplied by Shell oil company; and Cement waste (Kiln dust) which results from Portland cement manufacturing at Kufa cement plant, Iraq which using the wet process for producing cement. The chemical composition of cement waste shown in Table 1, and scanning electron microscopy (SEM) was used for structural analysis of cement waste as shown in Fig. 1.

\begin{tabular}{cc} 
Material & wt.\% \\
\hline $\mathrm{SiO}_{2}$ & 11.11 \\
\hline $\mathrm{Al}_{2} \mathrm{O}_{3}$ & 2.38 \\
\hline $\mathrm{Fe}_{2} \mathrm{O}_{2}$ & 2.55 \\
\hline $\mathrm{CaO}$ & 46.29 \\
\hline $\mathrm{MgO}$ & 1.12 \\
\hline $\mathrm{SO}_{3}$ & 0.59 \\
\hline $\mathrm{Cl}$ & 0.12
\end{tabular}

Table 1 Chemical composition of cement waste 1. táblázat A cement hulladék kémiai összetétele

\begin{tabular}{lcccc} 
& \multicolumn{5}{c}{ Matches composition ratio, pphr } \\
& $\mathbf{C}_{1}$ & $\mathbf{C}_{2}$ & $\mathbf{C}_{3}$ & $\mathbf{C}_{4}$ \\
$\begin{array}{l}\text { SBR type KER 1502 } \\
\text { (23.5\% Styrene) }\end{array}$ & 100 & 100 & 100 & 100 \\
\hline Zinc oxid & 5 & 5 & 5 & 5 \\
\hline Stearic acid & 2 & 2 & 2 & 2 \\
\hline Paraphinic wax & 2 & 2 & 2 & 2 \\
\hline Processing oil & 5 & 5 & 5 & 5 \\
\hline Antioxidant 6PPD & 0.5 & 0.5 & 0.5 & 0.5 \\
\hline Accelerator MBS & 1 & 1 & 1 & 1 \\
\hline Sulfur & 1.5 & 1.5 & 1.5 & 1.5 \\
\hline Carbon black (CB) & 10 & 20 & 30 & 35 \\
\hline Cement waste (CW) & 10 & 20 & 30 & 35 \\
\hline
\end{tabular}

Table 2 Samples' ingredients

2. táblázat A minták összetétele

\subsection{Sample preparation and testing}

The raw material batches illustrated in Table. 2 had been processed by roll mill machine type Comerio Ercole Busto Avsizo with $20 \mathrm{rpm}$ rotating speed, which contains two rolls see that the deviations in rheological properties are dependent on the amount of $\mathrm{CW} / \mathrm{CB}$ additives. At the initial stage of processing, the rubber is primarily heated where the viscosity is decreased and the torque is decreased consequently. In this earlier phase, the rubber compound begins to vulcanize and transform to elastic solid and the torque starts recovering. The minimum shear stress can be recorded also where the molecular chain scission may be occurred. The torque continues to rise up which proves that the crosslinking has been occurred and dominates the rubber structure [38].

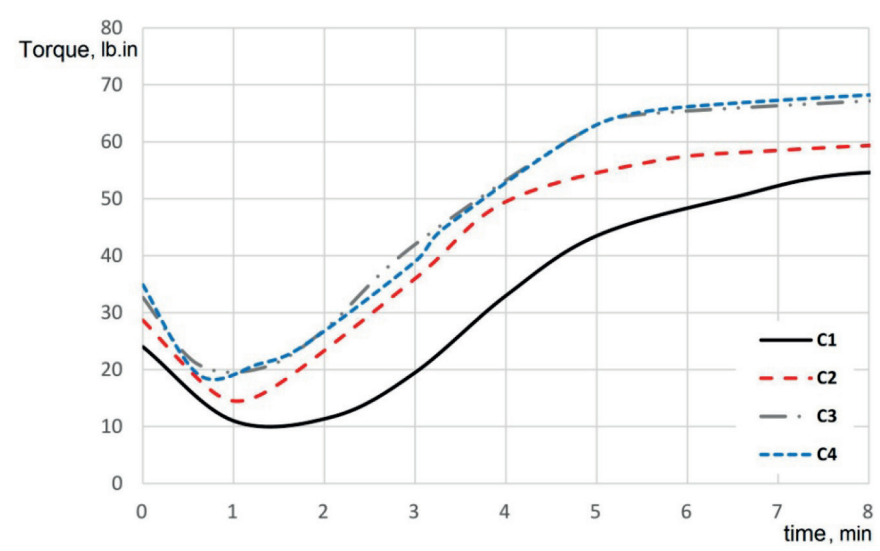

Fig. 2 Rheograph of $S B R / C W / C B$ tricomposite at $165^{\circ} \mathrm{C}$ with different percentages additives of $\mathrm{CW} / \mathrm{CB}(\mathrm{C} 1, \mathrm{C} 2, \mathrm{C} 4$ and $\mathrm{C} 4$ batches)

2. ábra SBR/CW/CB háromkomponensü rendszer Rheograph nyomaték görbéje 165 ${ }^{\circ} \mathrm{C}$-on különböző CW/CB adagolás esetén (C1, C2, C3 és C4 minták)

Figs. 5, 6 and 7 shows the variation in $\tau_{\mathrm{i}}, \tau_{\min }$, and $\tau_{\max }$ due to CW/CB additives and temperatures. From Fig. 5 we can observe that the increase of initial torque $\left(\tau_{i}\right)$ was linear as the percentage of additives increases. It was 0.44 at $165^{\circ} \mathrm{C}$ and $175^{\circ} \mathrm{C}$. After that it increased to 0.54 at $185^{\circ} \mathrm{C}$. This is an early indication that the SBR/CW/CB tricomposite is behaving differently at this particular temperature, where is some sort of internal structural changes have been occurred like crosslinking as we mentions above.

Fig. 6 shows that the highest $\tau_{\min }$ and $\tau_{\max }$ values were at 30 pphr CW/CB, where the SBR/CW/CB tricomposite has reached the optimum torque improvement. The rate of linear trend in Fig. 7 for all CW/CB filler percentages is 0.82 . Overall torque values obtained from rheographs increase positively 
with the increasing of the CW/CB additives percentage. This behavior is due to the performance and density of crosslinking inside rubber chains structure and that leads to increase vulcanization efficiency and rubber viscosity [39].

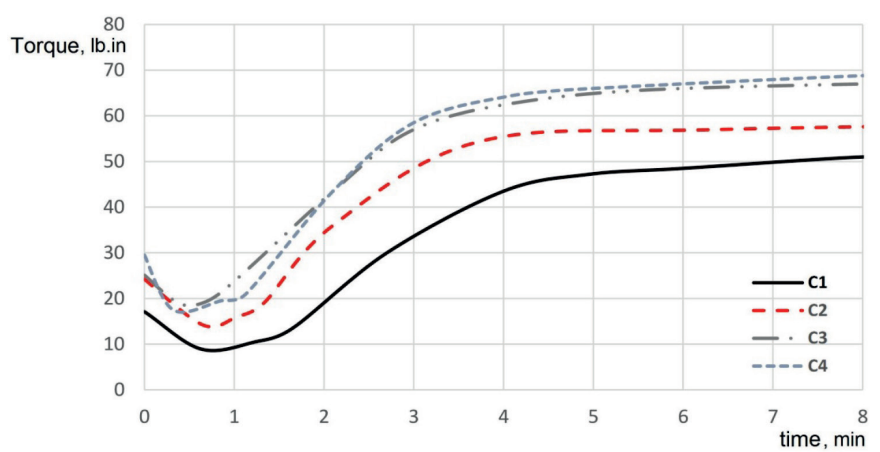

Fig. 3 Rheograph of $S B R / C W / C B$ tricomposite at $175^{\circ} \mathrm{C}$ with different percentages additives of $C W / C B(C 1, C 2, C 4$ and $C 4$ batches $)$

3. ábra $S B R / C W / C B$ háromkomponensü rendszer Rheograph nyomaték görbéje $175^{\circ} \mathrm{C}$-on különbözö CW/CB adagolás esetén (C1,C2, C3 és C4 minták)

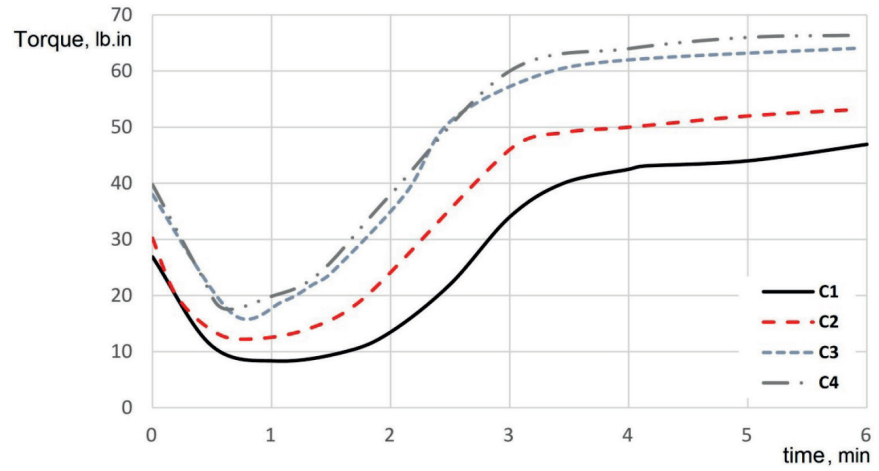

Fig. 4 Rheograph of SBR/CW/CB tricomposite at $185^{\circ} \mathrm{C}$ with different percentages additives of $C W / C B(C 1, C 2, C 4$ and $C 4$ batches)

4. ábra $S B R / C W / C B$ háromkomponensü rendszer Rheograph nyomaték görbéje $185{ }^{\circ} \mathrm{C}$-on különböző CW/CB adagolás esetén (C1, C2, C3 és C4 minták)

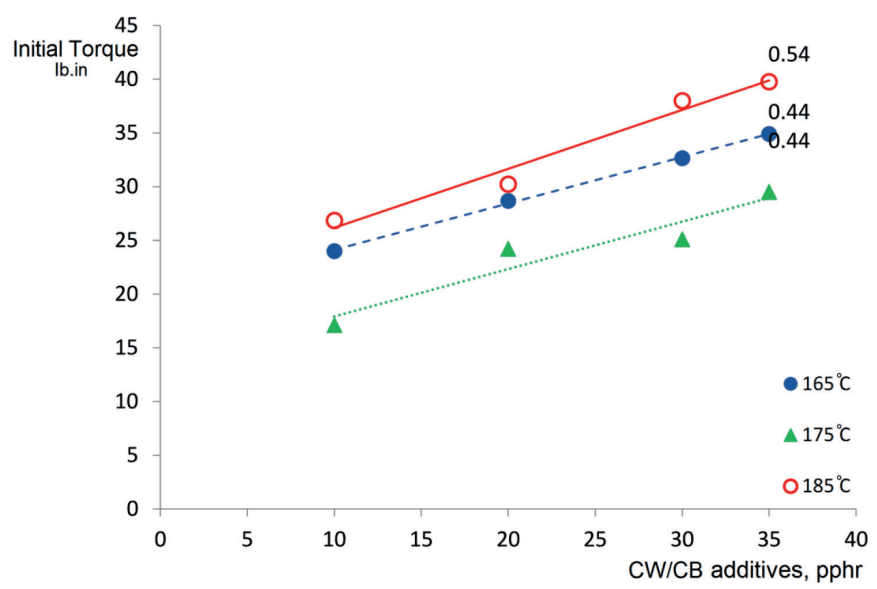

Fig. 5 Initial torque of $S B R / C W / C B$ tricomposite as a function of $C W / C B$ additions at $165^{\circ} \mathrm{C}, 175^{\circ} \mathrm{C}$ and $185^{\circ} \mathrm{C}$ temperature ranges

5. ábra SBR/CW/CB háromkomponensü rendszer kezdeti nyomatéka $165^{\circ} \mathrm{C}, 175^{\circ} \mathrm{C}$ és $185^{\circ} \mathrm{C}$-on a $\mathrm{CW} / \mathrm{CB}$ adagolás függvényében

\section{Conclusions}

1. The success of cement waste as an effective filler for improving the rheological properties of SBR has been proven by rheological tests.
2. The optimum of the rheological properties were obtained with CW/CB 30 pphr addition.

3. As a result of crosslinking enhancing for the interior structure of SBR tricomposite by CW/CB additives, the torque values $\left(\tau_{\mathrm{i},} \tau_{\min }\right.$ and $\left.\tau_{\max }\right)$ has been refined.

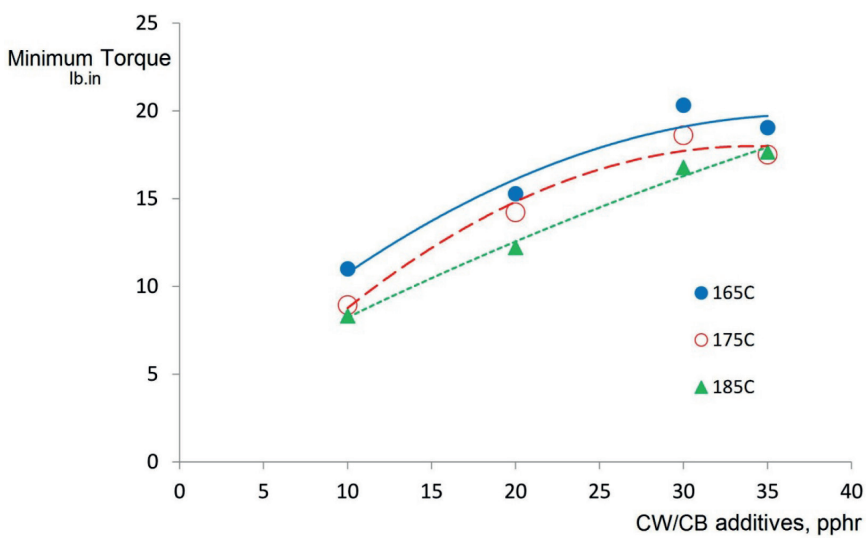

Fig. 6 Minimum torque $S B R / C W / C B$ tricomposite as a function of $C W / C B$ additions at $165^{\circ} \mathrm{C}, 175^{\circ} \mathrm{C}$ and $185^{\circ} \mathrm{C}$ temperature ranges

6. ábra $S B R / C W / C B$ háromkomponensü rendszer minimális nyomatéka $165^{\circ} \mathrm{C}$ $175^{\circ} \mathrm{C}$ és $185^{\circ} \mathrm{C}$-on a $\mathrm{CW} / \mathrm{CB}$ adagolás függvényében

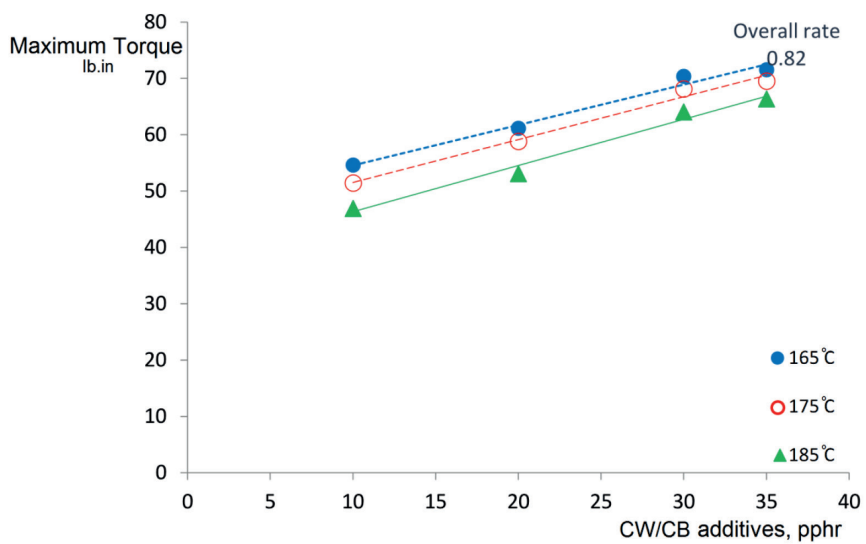

Fig. 7 Maximum torque $S B R / C W / C B$ tricomposite as a function of $C W / C B$ additions at $165^{\circ} \mathrm{C}, 175^{\circ} \mathrm{C}$ and $185^{\circ} \mathrm{C}$ temperature ranges

7. ábra $S B R / C W / C B$ háromkomponensü rendszer maximális nyomatéka $165^{\circ} \mathrm{C}$ $175^{\circ} \mathrm{C}$ és $185^{\circ} \mathrm{C}$-on a $\mathrm{CW} / \mathrm{CB}$ adagolás függvényében

References

[1] Al-Maamori, M. H., - Al-Mosawi, A. I. (2013): Rubber technology: experimental studies, $1^{\text {st }}$ edition, LAP Lambert Academic Publishing, Germany. ISBN:978-3659393105

[2] White, J. L. (1995): Rubber processing: technology, materials, and principles, $1^{\text {st }}$ edition, Hanser Publisher. ISBN: 978-1569901656

[3] Al-Mosawi, A. I. (2015): Experimental data: Polymers and rubber, $1^{\text {st }}$ edition, United States: Createspace Independent Publishing Platform. ISBN: 978-1514657461

[4] Montes, S., - White, J. L. - Nakajima, N. (1988): Rheological behavior of rubber carbon black compounds in various shear flow histories, Journal of Non-Newtonian Fluid Mechanics, Vol.28, Issue.2, pp.183-212. https://doi.org/10.1016/0377-0257(88)85039-0

[5] Roland, C. M. (2013): Rheological behavior and processing of unvulcanized rubber, in James E. Mark, Burak Erman and C. Michael Roland (authors) the science and technology of rubber, $4^{\text {th }}$ edition, pp.285-336. https://doi.org/10.1016/B978-0-12-394584-6.00006-6

[6] Song, Y. - Zeng, L. - Zheng, Q. (2017): Reconsideration of the rheology of silica filled natural rubber compounds, The Journal of Physical Chemistry $B$ Vol.121, Issue.23, pp 5867-5875. https://doi.org/10.1021/acs.jpcb.7b02760

[7] Zaeimoedin, T. Z. - Kamal, M. M. - Aziz, A. K. C. (2016): Rheological properties and extrusion performance evaluation of silica filled epoxidized 
natural rubber (ENR) compounds as compared to natural rubber/ butadiene rubber (NR/BR) compound, Advanced Materials Research, Vol.1133, pp.236-240.

https://doi.org/10.4028/www.scientific.net/AMR.1133.236

[8] Yaacob, H. - Mughal, M. A. - Jaya, R. P. - Hainin, M. R. - Jayanti, D. S. Wan. C. N. C. (2016): Rheological properties of styrene butadiene rubber modified bitumen binder, Jurnal Teknologi, Vol.78, No.7-2, pp. 121-126. https://doi.org/10.11113/jt.v78.9503

[9] Wiessner, S. (2015): Rheological behavior and rubber processing, in S. Kobayashi, K. Müllen (eds.) Encyclopedia of Polymeric Nanomaterials, Springer, Berlin, Heidelberg, pp.1-10. https://doi.org/10.1007/978-3-642-29648-2

[10] Crié, A. - Baritaud, C. - Valette, R. - Vergnes, B. (2015): Rheological behavior of uncured styrene-butadiene rubber at low temperatures, pure and filled with carbon black, Polymer engineering and Science, Vol.55, Issue.9, pp.2156-2162. https://doi.org/10.1002/pen.24090

[11] Al-Maamori, M. H. (2006): Mechanical properties of polymeric composite materials, Ph.D thesis, UOT, IRAQ

[12] White, J. L. (2005): Rheological behavior and processing of unvulcanized rubber, Chapter 6 in James E. Mark, Burak Erman and Frederick R. Eirich (eds.) Science and Technology of Rubber, $3^{\text {rd }}$ edition, pp.237-319. https://doi.org/10.1016/B978-012464786-2/50009-2

[13] Mostafa, A. - Abouel-Kasem, A. - Bayoumi, M. - El-Sebaie, M. (2010): Rubber-filler interactions and its effect in rheological and mechanical properties of filled compounds, Journal of Testing and Evaluation, Vol.38, No.3, pp.347-359. https://doi.org/10.1520/JTE101942

[14] Al-Maamori, M. H. - Al-Mosawi, Ali I. - Abdulsada, S. A. (2016): Rheological behavior of Rubber Blends», $2^{\text {nd }}$ International conference on innovative trends in Engineering, Science and Management (ICITESM-16), YMCA , Jai Singh Road, Delhi, India.

[15] Boochathum, P. (2014): Rheological Behaviour of Natural Rubber Based Blends, Chapter 18 in S. Thomas, C.H. Chan, L. Pothen, Rajisha K. R., H. Maria (eds), Natural rubber materials: volume 1: Blends and IPNs, pp. 394 - 440 . https://doi.org/10.1039/9781849737647-00394

[16] Münstedt, H. (1981): Rheology of rubber-modified polymer melts, Polymer engineering and Science, Vol.21, Issue.5, pp.259-270. https://doi.org/10.1002/pen.760210503

[17] Gömze, L. A. (2015): Compilation of Scientific Papers I, GREX Engineering Service Ltd. publisher, Hungary. ISBN: 978-963-12-3088-8

[18] Al-Mosawi, A. I. - Hashim, A. A. - Al-Maamori, M. H. (2019): Production of high performance mountings by using rubber-polymer waste, Open Access Library Journal, Vol.6, No.4, pp. 1-6. https://doi.org/10.4236/oalib.1105368

[19] Al-Mosawi, A. I. (2013): Environmental impact study for the establishment of an investment project to process the palms agricultural waste, Journal of University of Babylon, Special Issue for $5^{\text {th }}$ International conference of environmental science, Environmental research center, University of Babylon, IRAQ.

[20] Al-Maamori, M. H. - Al-Mosawi, A. I. (2014): Manufacturing of composite rubber material for the manufacturing of rubber rubbles and other reinforced by a brass Bushes used in mechanical and electrical couplings, Central Organization for Standardization and Quality Control (COSQC), Patent No.3913, International Classification (C08C19/42), Iraqi Classification (4), IRAQ.

[21] Al-Mosawi, A. I. - Al-Maamori, M. H. - Abdulsada, S. A. (2015): Mechanical Properties of Acrylonitrile - Butadiene Rubber Reinforced by Cement Waste, Journal of Thin Films, Coating Science Technology and Application, Vol.2, No.2, pp. 13-16.

[22] Al-Salem, S. M. - Lettieri, P. - Baeyens, J. (2009): Recycling and recovery routes of plastic solid waste (PSW): A review, Waste Management, Vol.29, Issue.10, pp.2625-2643. https://doi.org/10.1016/j.wasman.2009.06.004

[23] Al-Mosawi, A. I. - Abdulsada, S. A. - Hashim, A. A. (2018): Sustainable Procedure for Using Waste of Date Seeds as a Reinforcement Material for Polymeric Composites, Open Access Library Journal, Vol. 5, Issue. e4384, pp.1-8. https://doi.org/10.4236/oalib.1104384
[24] Al-Mosawi, A. I. - Abdulsada, S. A., and Rijab, M.A. (2017) Recycling Procedure of Plant Waste for Manufacturing Green Composite Material, Journal of Catalyst and Catalysis, Vvol. 5, Issue. 4, pp.211-214.

[25] Malik, N. - Kumar, P. - Shrivastava, S. - Ghosh, S. B. (2017): An overview on PET waste recycling for application in packaging, International Journal of Plastics Technology, Vol. 21, Issue.1, pp.1-24. https://doi.org/10.1007/s12588-016-9164-1

[26] Al-Mosawi, A. I. - Abdulsada, S. A. - Kónya, C. - Szemere, G. (2017): Orange Peel Waste as a Reinforcing Material for Plasticised PVC, GRANT journal, Vol. 6, Issue. 2, pp.88-91.

[27] Al-Mosawi, A. I. - Al-Maamori, M. H. - Marossy, K. (2019): Rheological properties of NBR/CR blends as a function of silicon dioxide grain size gradation, Épitöanyag-Journal of Silicate Based and Composite Materials, Vol.71, No.2, pp.43-45. https://doi.org/10.14382/epitoanyag-jsbcm.2019.8

[28] Abdulsada, S. A. - Al-Mosawi, A. I. - Hadi, A. A. A. - Saad, K. - Samir, H. (2017): Waste Plants as a Green Inhibitor for Reinforced Concrete, Recent Trends in Civil Engineering \& Technology, Vol. 7, Issue. 3, pp.53-58.

[29] Al-Mosawi, A. I. - Abdulsada, S. A. (2015): Recycling of waste materials: a review. ${ }^{\text {st }}$ edition, LAP Lambert Academic Publishing, Germany. ISBN: 978-3659695308

[30] Bolden, J. - Abu-Lebdeh, T. - Fini, E. (2013): Utilization of recycled and waste materials in various construction applications, American Journal of Environmental Science, Vol.9, Issue.1, pp.14-24. https://doi.org/10.3844/ajessp.2013.14.24

[31] Abdulsada, S. A. - Al-Mosawi, A. I. (2015): Tensile strength of a new recyclable and environment friendly composite material, Ciência e Técnica Vitivinícola, Vol.30, Issue.1, pp. 32-40.

[32] Ondrušová, D. - Domčeková, S. - Pajtášová, M. - Dubec, A. - Mičicová, Z. - Pecušová, B. (2017): Alternative filler based on the waste from glass production and its effect on the rubber properties, Procedia Engineering, Vol.177, pp. 462-469. https://doi.org/10.1016/j.proeng.2017.02.246

[33] Moreira, V. X. - Soares, B. G. (2002): Study of Utilization of Ground EVA Waste as Filler in NBR Vulcanizates, Polymers and Polymer Composites, Vol.10, Issue.5, pp. 381-390. https://doi.org/10.1177/096739110201000505

[34] Ahmeda, K. - Nizamib, S. S. - Riza, N. Z. (2014): Reinforcement of natural rubber hybrid composites based on marble sludge/Silica and marble sludge/rice husk derived silica, Journal of Advanced Research, Vol.5, Issue.2, pp. 165-173. https://doi.org/10.1016/j.jare.2013.01.008

[35] Rattanapan, A. - Paksamut, J. - Pakeyangkoon, P. - Tuampoemsab, S. (2014): Waste silicon carbide as filler for natural rubber compounds, Advanced Materials Research, Vol. 979, pp. 155-158. https://doi.org/10.4028/www.scientific.net/AMR.979.155

[36] Martín-Cortés, G. R. - Esper, F. J. - de Araujo, A. J. S. - Hennies, W. T. - Valenzuela, M. G. S. - Valenzuela-Díaz, F. R. (2016) Replacement of carbon black on natural rubber composites and nanocomposites - part 1, In: Carpenter J.S. et al. (eds.) Characterization of Minerals, Metals, and Materials 2015. Springer, Cham, pp. 145-152. https://doi.org/10.1007/978-3-319-48191-3_18

[37] ASTM D2084-17 (2017): Standard test method for rubber propertyvulcanization using oscillating disk cure meter, ASTM International, West Conshohocken, PA. https://doi.org/10.1520/D2084-17

[38] Demirhana, E. - Kandemirlib, F. - Kandemirli, M. (2007): The effects of furnace carbon blacks on the mechanical and the rheological properties of SBR1502 styrene butadiene rubber, Materials and Design, Vol.28, Issue.4, pp.1326-1329. https://doi.org/10.1016/j.matdes.2006.01.002[39] Zhang, A. - Wang, L. - Zhou, Y. (2003): A study on rheological properties of carbon black extended powdered SBR using a torque rheometer, Polymer Testing, Vol.22, Issue.2, pp.133-141. https://doi.org/10.1016/S0142-9418(02)00061-2

$\underline{\text { Ref.: }}$

Al-maamori, Mohammed H. - Hashim, Abbass A. - Al-Mosawi, Ali I. - Abdulsada, Shaymaa Abbas - Marossy, Kálmán: Rheological investigation of $S B R / C W / C B$ tricomposite used to create a sustainable procedure for idler rollers production Építőanyag - Journal of Silicate Based and Composite Materials, Vol. 71, No. 5 (2019), 144-147. p. https://doi.org/10.14382/epitoanyag-jsbcm.2019.25 